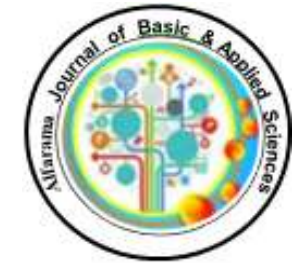

ISSN 2682-275X
Alfarama Journal of Basic \& Applied Sciences

Faculty of Science Port Said University https://ajbas.journals.ekb.eg

ajbas@sci.psu.edu.eg

http://sci.psu.edu.eg/en/

July 2021, Volume 2, Issue 2

DOI: 10.21608/AJBAS.2021.72460.1051

Submitted: 05 /05 / 2021

Accepted: $08 / 06 / 2021$

Pages: 239-252

\title{
Epizotological and Bacteriological Investigations on Vibrio spp. Isolated from some Red Sea Fish Larvae at Hurghada, Egypt
}

\author{
Islam Ibrahim Abogabal ${ }^{1}$, Ali Hassan Ibrahim ${ }^{2}$, Mohamed Ahmed Abu El-Regal ${ }^{3,4}$ \\ and Mahmoud Hashem Mohammed ${ }^{5}$ \\ ${ }^{1}$ Water quality management, Egyptian Environmental Affairs Agency (EEAA), Hurghada, Egypt. \\ ${ }^{2}$ Botany Department, Faculty of Science, Port Said University, Egypt. \\ ${ }^{3}$ Department of Marine Biology, Faculty of Marine Science, King Abdulaziz University, Kingdom of \\ Saudi Arabia. \\ ${ }^{4}$ Marine Science Department, Port-Said University, Port-Said, Egypt. \\ ${ }^{5}$ Faculty of Veterinary Medicine- New Valley University, New Valley, Egypt. \\ *Corresponding author: islameeaa@yahoo.com
}

\begin{abstract}
Fish larvae were captured seasonally (2018) using light trap from coral reef lagoon of the Marine Biological Station at Hurghada on the Egyptian Red Sea coast. A total of 182 larvae belonging to seven fish families were collected and identified based on the morphological characteristics. The diseased larvae were clinically examined and macerated tissues were injected onto Trypton Soy Agar $(1.5 \% \mathrm{NaCl})$ and incubated at $25.5{ }^{\circ} \mathrm{C}$ for 25 days. The obtained bacterial isolates were identified as $V$. harveyi, $V$. parahaemolyticus, $V$. alginolyticus, $V$. vulnifacus, non virulence $V$. cholerae and unidentified Vibrio species by the morphological and biochemical characterization. The prevalence ratio of bacterial infection of all infected larvae was 101 larvae (55.5\%). The highest number of infected larvae was recorded in summer (45 larvae, 86.5\%), while the lowest was recorded in winter (10 larvae, 25\%). The most frequently encountered Vibrio $s p$. was $V$. harveyi which was isolated from 28 fish larvae followed by $V$. parahaemolyticus which was isolated from 25 fish larvae. The delicate round herring exhibit the highest prevalence of infection with different Vibrio spp. (58.3\%) during different seasons.
\end{abstract}

\section{Keywords}

Vibrio, fish larvae, Fish pathogen, Light trap, Red Sea 


\section{INTRODUCTION}

Fish resource sector with its natural fisheries and fish farming is considered as one of the important traditional components for attaining food security and bridging the widening food gap, and is a major part of the Egyptian economy [1]. The Egyptian Red sea costs is distinguished by specific habitats and threatened species, it has been shown itself to be as an excellent laboratory for several researchers and the study of relatively rapid changes of short duration in the marine environment. Unfortunately, the growth of the coastal urban areas generates a range of threats to the nearby shoreline habitats [2]. Environmental pollution on the Red Sea shore has caused the loss of up to 70 percent of its fishing wealth during the past 20 years. Additionally, the annual growing of population increases the pressure on fisheries due to increased demand for fish [1].

Mortality during the early stages is a major cause of the natural variations in the size and recruitment strength of marine fish populations. One of the major causes for the low and unpredictable survival in early phases of marine fish is the prevalence of bacterial diseases [3]. Inception of these diseases could be attributed to the unsuitable environmental conditions such as low available oxygen, and high alkalinity and ammonia due increased population activities, which increase the microbial pollution [4].

It has long been known that the external surface of fish eggs is an outstanding habitat for bacteria colonization and reduplication. Following to egg hatching, the fish larvae in yolk-sac phase are immediately exposed to microorganisms including bacteria which are existed on egg surface. Furthermore, these uncovered larvae become subjected to the surrounding marine water bacteria which could lead to larval diseases and death [5]. Vibrio is a genus of these prevalent bacteria which attach fish larvae in marine habitat causing a serious disease known as Vibriosis [6]. Vibriosis have numerous pathogenic species (V. harveyii, V. vulnificus, V. alginolyticus, V. fisherii, V. cholerae, V. ordalii, V. parahaemolyticus and several others). It causes haemorrhagic septicaemia, leucopenia and high mortalities with significant economic impact [7].

Vibrio spp (Family Vibrionaceae) can be defined as a halophilic, facultatively aerobic, gram negative rod-shaped bacteria. It is more widespread in aquatic habitats polluted with organic matter at water temperatures in the mesophilic range [8]. Vibrio spp. has been recovered from many diseased marine animals, including shrimps [9], Asian seabass [10], abalone [11], marine teleost's [12], red drum [13] and sea horse [14]. However, the genus Vibrio has and is expected to continue expanding with the addition of several new species annually [15]. Consequently, it was of paramount importance to have a method which was able to reliably and efficiently differentiate the numerous Vibrio species. The isolation and identification of bacteria from the aquatic environment is expanding at a rapid rate. This has happened due to an increase in aquaculture research, an increase in intensive fish farming systems, an increase in the international trade of live aquatic animals and products, and the emergence of new diseases. More and more laboratories are becoming involved in the isolation and identification of these bacteria in either a diagnostic or research capacity [16].

Researches on bacteria that attach fish larvae in the Red Sea are scarce due to the challenges in sample collection and identification [17]. So this work was undertaken to identify fish larvae at Hurghada region during the four seasons and the associated marine water physiochemical properties. Furthermore, the prevalence of different Vibrio spp. during different seasons was explored. 


\section{MATERIALS AND METHODS}

\subsection{Study area}

The investigated area is situated at $27^{\circ} 17^{\prime} 6^{\prime \prime} \mathrm{N}$ and $33^{\circ} 46^{\prime} 22^{\prime \prime} \mathrm{E}$ facing the National Institute of Oceanography and Fisheries (NIOF) in the northern part of Hurghada city (about $5 \mathrm{~km}$ north of Hurghada city (Fig.1). This area is recognized by coral reefs existence which have many fish species at larval and early growth phase.

\subsection{Marine water physicochemical properties}

A Multi-probe instrument (Aquaread AP 5000) was used to assess seawater parameters such as temperature, salt concentration, $\mathrm{pH}$ and dissolved oxygen, in the investigated area, during the four seasons from January to December (2018). Additionally, water specimens were kept in clean dark brown polyethylene vials to be used for determination of ammonia concentration using a Pye-Unicam Spectrophotometer (Model PU-8600) [18]. Position (Co- ordinates) was measured by GPS (Magellan).

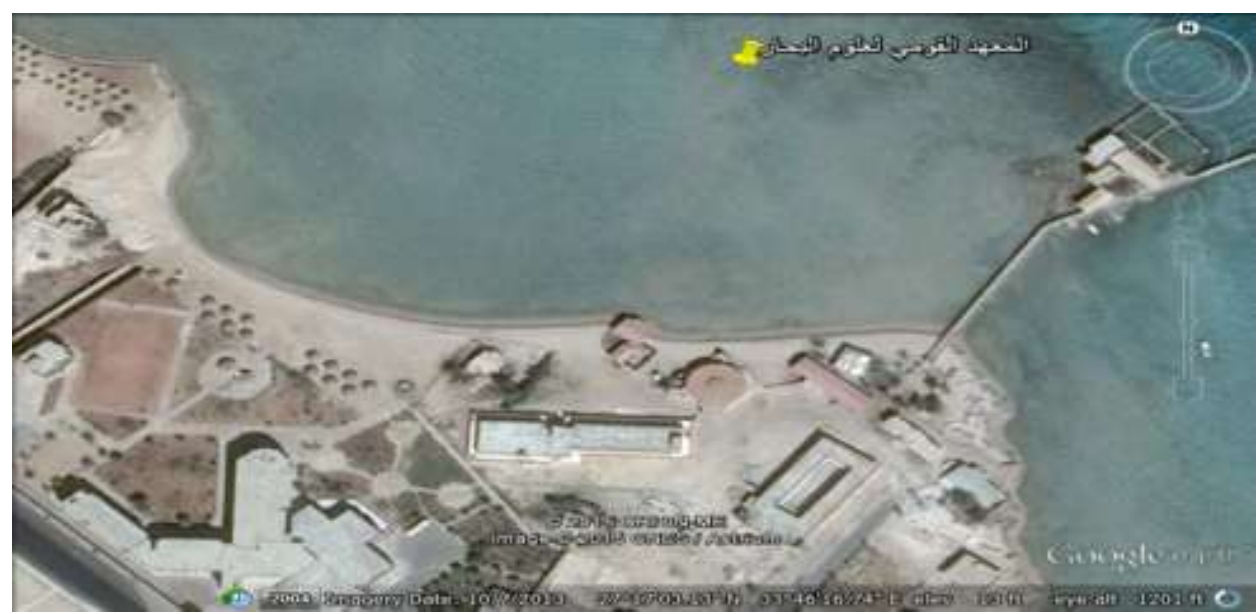

Figure 1: Photo showing the Google earth of National Institute of Oceanography and Fisheries (NIOF).

\subsection{Fish larvae collection}

A total of 182 fish larvae with average length $0.5 \pm 2(\mathrm{~mm})$ were freshly captured seasonally from winter to autumn (2018) using Light trap (Fig. 2). The trap was implemented in seawater just after sundown and continued for 120 minutes $(2 \mathrm{~h})$. All larvae were stabilized at bottom of the gathering bucket and instantly were transferred to the laboratory. These larvae were stored and characterized to the lowest possible taxonomic level based on morphological features [19]. After that, fish larvae were subjected to clinical examination and bacteriological studies. 


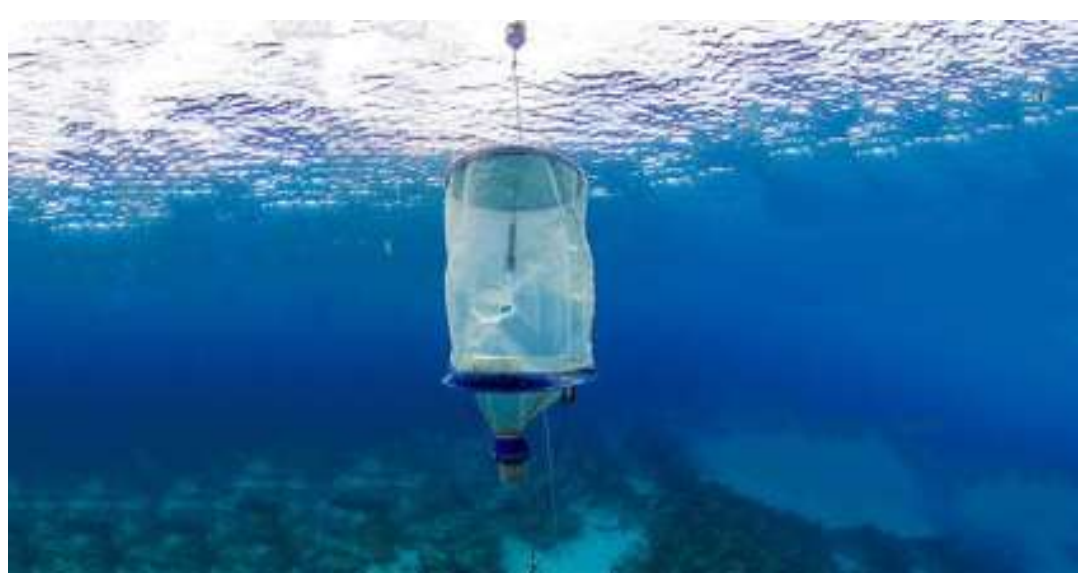

Figure 2: Photo showing Light trap.

\subsection{Clinical examination of fish larvae}

The fish larvae were examined according to Santos et al. [20] for the detection of the clinical signs on the external body surface and post mortem lesions on the internal organs.

\subsection{Bacterial isolation and identification}

Fish larvae macerated tissues (outer skin ulcers) were injected onto1.5\% $\mathrm{NaCl}$ Trypton Soy Agar (TSA) (Oxoid) and incubated at $25.5{ }^{\circ} \mathrm{C}$ for $2-5$ days following the procedure of Farmer et al. [21]. The pure suspected colonies of bacteria were sub cultured, incubated and recognized by morphological and biochemical tests following the procedure of Alsina and Blanch [22]. Additionally, commercial API 20E strips (BioMerieux, France) were used for bacteria identification according to instructions of the manufacturer.

\section{RESULTS}

\subsection{Physicochemical parameters}

Values of $\mathrm{pH}$ were always slightly alkaline in tested water samples where they were ranged from $8.0 \mathrm{r}$ in summer to 8.82 in winter season in the studied area. The surface water temperature varied from $20 .\left\{r^{\circ} \mathrm{C}\right.$ to $31^{\circ} \mathrm{C}$. The lowest temperature was reported in winter, whereas the highest one was recorded in summer season (Fig.3). 

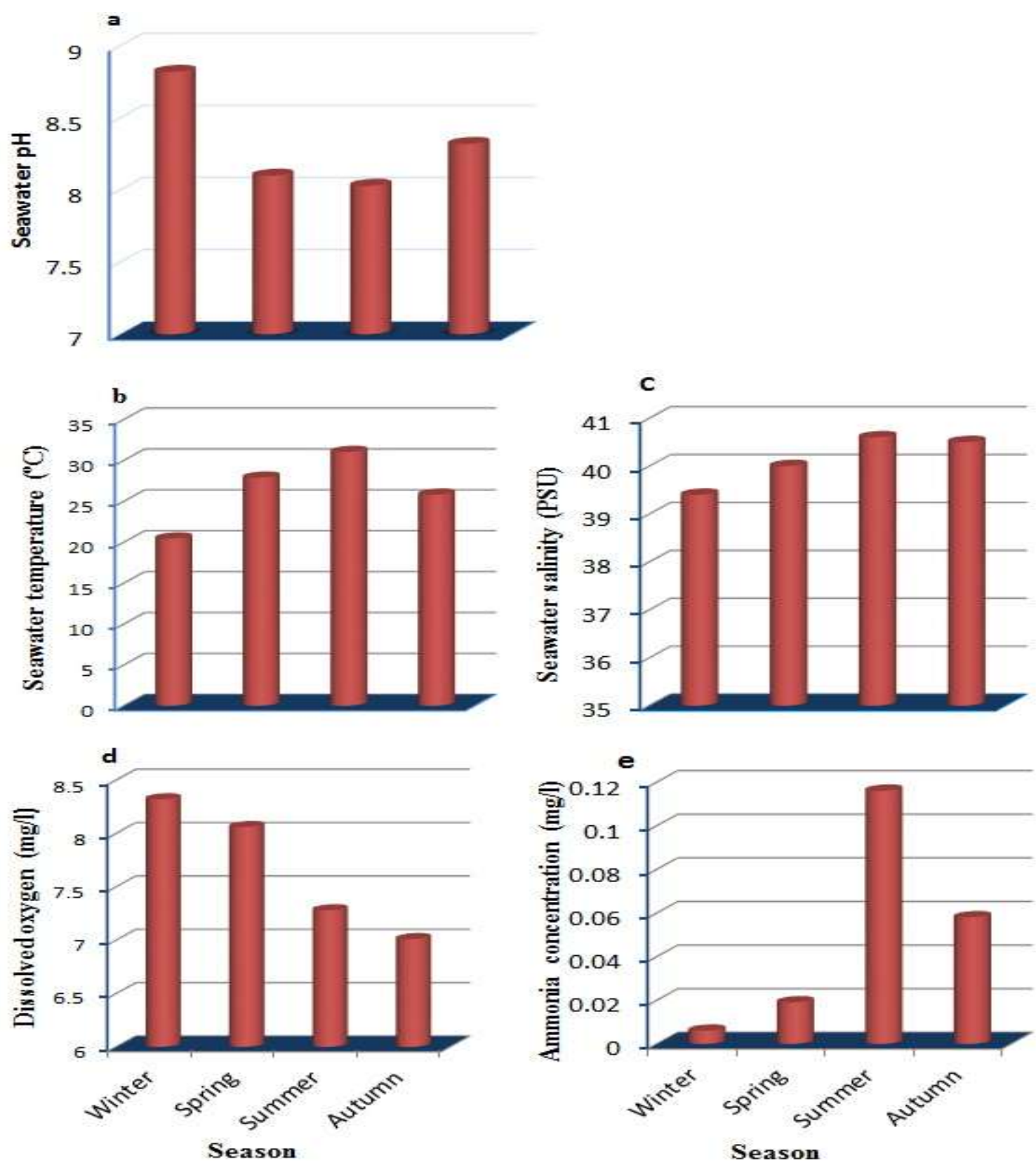

Figure 3: Seasonal changes in $\mathrm{pH}(\mathrm{a})$, temperature (b), salinity (c), dissolved oxygen (d) and Ammonia concentration (e) of seawater at NIOF in Hurghada during 2018. 
In summer season, seawater salinity reached the highest value which was about 40.6 PSU, whereas winter season recorded the lowest value which was about 39.4 PSU (Practical Salinity Unit). The measurements of dissolved oxygen ranged from 7.01 in autumn to $8.32 \mathrm{mg} / \mathrm{l}$ in winter in the investigated area. Ammonia showed the highest concentration in summer $(0.116 \mathrm{mg} / \mathrm{l})$ and the lowest concentration in winter (0.006 mg/l) (Fig. $\left.{ }^{\top}\right)$.

\subsection{Identification of fish larvae in the investigated area}

A total of 182 fish larvae belonging to seven fish families were collected of which larvae of the family Clupeidae (Sardine and herring) were the most abundant 120 (66\%) followed by family Phosichthyidae 15 (8\%). The least abundant was the family Callionymidae and family Apogonidae with 7 and 6 larvae, respectively (Table 1). Sardines (Clupeidae) were represented by the delicate round herring, Spratelloides delicatulus and lightfishes (Phosichthyidae) were represented by Vinciguerria mabahiss. Larvae of Apogonidae and Microdesmidae could not be identified beyond the family level (Fig.4), where most larvae are very difficult to identify, some were identified to the species level, others were identified to generic level and other taxa were identified as family.

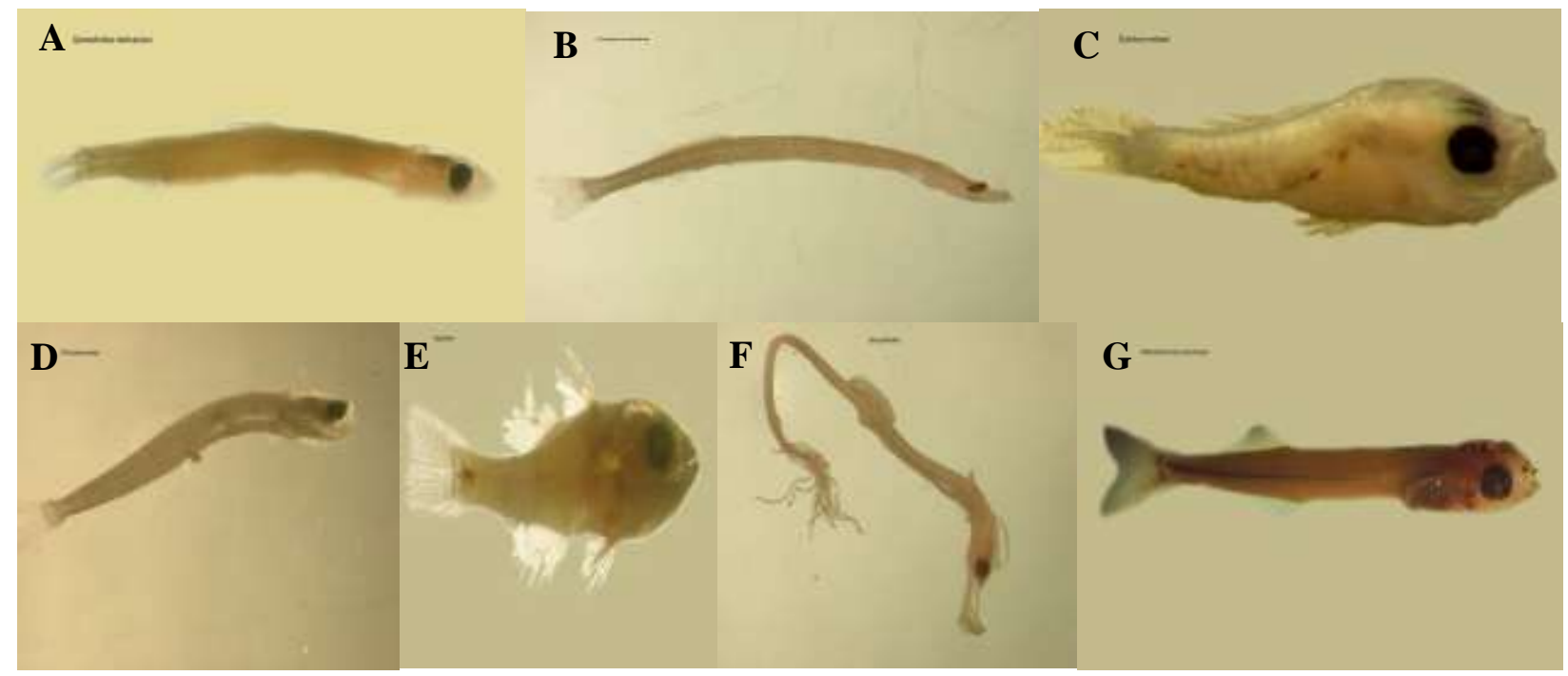

Figure 4: Photo showing (A) Spratelloides delicatulus (B) Vinciguerria mabahiss (C) Callionymus sp. (D) Microdesmidae (E) Apogonidae (F) Syngnathoides biaculeatus (G) Atherinomorus lacunosus

\subsection{Abundance of fish larvae during different seasons}

In general, the abundance of fish larvae was the highest value in spring (58 larvae), followed by summer (52 larvae), whereas the lowest abundance was recorded in autumn (32 larvae). Sardine (Spratelloides delicatulus) show the highest prevalence rate during all different seasons, while Dragonets (Callionymus sp.) and Apogonidae (Cardinalfishes) are absent in winter and autumn(Table1). 
Table (1): Abundance of fish larvae during different seasons

\begin{tabular}{|c|c|c|c|c|c|c|c|c|c|c|}
\hline \multirow[b]{2}{*}{ Family } & \multirow{2}{*}{ Species } & \multirow[b]{2}{*}{$\begin{array}{c}\text { Common } \\
\text { name }\end{array}$} & \multicolumn{2}{|c|}{ Winter } & \multicolumn{2}{|c|}{ Spring } & \multicolumn{2}{|c|}{ Summer } & \multicolumn{2}{|c|}{ Autumn } \\
\hline & & & No. & $\%$ & No. & $\%$ & No. & $\%$ & No. & $\%$ \\
\hline Clupeidae & $\begin{array}{l}\text { Spratelloides } \\
\text { delicatulus }\end{array}$ & $\begin{array}{l}\text { The delicate } \\
\text { round herring }\end{array}$ & 30 & 75 & 30 & 51.7 & 30 & 57.7 & 30 & 93.8 \\
\hline Phosichthyidae & $\begin{array}{l}\text { Vinciguerria } \\
\text { mabahiss }\end{array}$ & Lightfishes & 3 & 7.5 & 6 & 10.3 & 5 & 9.6 & 1 & 3.1 \\
\hline Syngnathidae & $\begin{array}{c}\text { Syngnathoides } \\
\text { biaculeatus }\end{array}$ & Pipefishes & 2 & 5 & 6 & 10.3 & 6 & 11.5 & 0 & 0 \\
\hline Microdesmidae & Microdesmidae & Wormfishes & 2 & 5 & 7 & 12.1 & 2 & 3.8 & 0 & 0 \\
\hline Atherinidae & $\begin{array}{c}\text { Atherinomorus } \\
\text { lacunosus }\end{array}$ & $\begin{array}{l}\text { hardyhead } \\
\text { silverside }\end{array}$ & 3 & 7.5 & 2 & 3.4 & 3 & 5.8 & 1 & 3.1 \\
\hline Callionymidae & $\begin{array}{l}\text { Callionymus } \\
\text { sp. }\end{array}$ & Dragonets & 0 & 0 & 3 & 5.2 & 4 & 7.7 & 0 & 0 \\
\hline Apogonidae & Apogonidae & Cardinalfishes & 0 & 0 & 4 & 6.9 & 2 & 3.8 & 0 & 0 \\
\hline \multicolumn{3}{|c|}{ Total } & 40 & 100 & 58 & 100 & 52 & 100 & 32 & 100 \\
\hline
\end{tabular}

\subsection{Clinical signs on clinically diseased fishes}

Larvae revealed the presence of diseases signs on $55.5 \%$ of them. Infection was microscopically observed by the changes in swimming behaviors from rapid movement(Uninfected larvae) to sluggish movement(Infected larvae), petechial hemorrhage in skin, minute ulcers in the tail region and in post mortem picture gut necrosis wase detected (Fig.5).

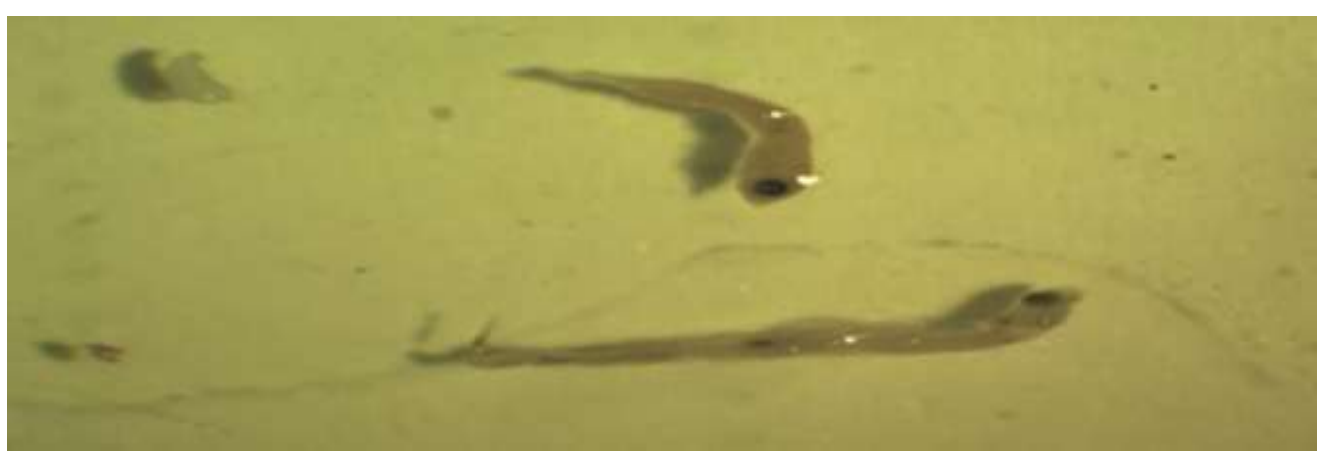

Figure 5: S. delicatulus larvae showing petechial hemorrhage on the skin. 


\subsection{Morphological characterization and Biochemical identification of the isolated bacteria}

One hundred and six (106) bacterial isolates were recoverd from skin ulcers external lesions of larvae. On TSA agar colonies appeared as smooth, rounded, white-to-cream-colored, on TCBS the colonies appeared yellow and greenish, smooth, circular, and convex. Most of isolates showed initial morphological character typical with those of genus Vibrio; the isolated bacteria were Gram-ve curved short rods, and motile (Fig. 6).
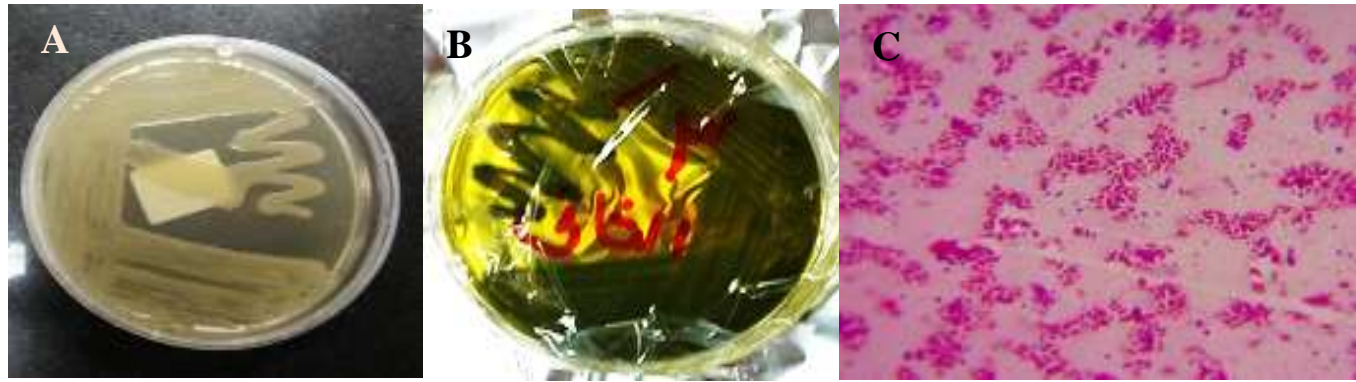

Figure 6: Morphological characteristics of Vibrio spp. (a) Bacterial colonies on TSA (b) Vibrio colonies on TCBS (c) gram negative rods.

The biochemical and morphological characteristics (Table 2) of all isolates showed variation and the isolated bacteria was identified as $V$. harveyi [28 isolates (15.4\%)], $V$. parahaemolyticus [25 isolates(10.4\%)], V. alginolyticus [15 isolates( 8.2\%)], V. vulnifacus [14 isolates(7.6\%)], V. cholerae [13 isolates $(7.1 \%)]$ and unidentified Vibrio species [11 isolates(6\%)].

3.6. Prevalence of infection of early stage larvae with different pathogenic Vibrio spp. during different seasons

About 101 fish larvae (55.5\%) from total early stage fish larvae were infected with pathogenic Vibrio species. The highest prevalence of infection was observed in summer 86.5\% (45 larvae) of all collected larvae during this season. Where, the lowest prevalence of infection was recorded in winter $25 \%$ of all collected larvae (10 larvae). All studied Vibrio species were recoverd in all seasons except $V$. vulnificus was absent in winter specimens. V. harveyi was the most frequently recoverd Vibrio sp. which was obtained in pure culture from 28 fish larvae followed by $V$. parahaemolyticus which was recovered from 25 fish larvae (Table 3 ).

\subsection{Prevalence of infection between different larvae during different seasons}

As shown in table (4), the delicate round herring (Spratelloides delicatulus) exhibit the highest prevalence of infection with different Vibrio spp. during different seasons (58.3\%), while the lowest prevalence of infection with Vibrio spp. was recorded in Wormfishes (Microdesmidae) (18.2\%) during different seasons. 
Table (2): Morphological and biochemical characteristics of the isolated bacteria infecting early stages of fish

\begin{tabular}{|c|c|c|c|c|c|}
\hline Test & $\begin{array}{c}V . \\
\text { alginolyticus. }\end{array}$ & $\begin{array}{c}V . \\
\text { parahemolatycus }\end{array}$ & $\begin{array}{l}\text { Isolates } \\
\text { V. harveyi }\end{array}$ & V. vulnifacus & V. cholerae \\
\hline Gram stain & $-\mathrm{Ve}$ rods & - Ve rods & $-\mathrm{Ve}$ rods & -Ve rods & -Ve rods \\
\hline Catalase & + & + & + & + & + \\
\hline $\begin{array}{l}\text { Cytochrome } \\
\text { oxidase }\end{array}$ & + & + & + & + & + \\
\hline Voges-Proskauer & - & - & - & - & - \\
\hline $\begin{array}{c}\text { Ornithine } \\
\text { decarboxylase }\end{array}$ & + & + & + & V & + \\
\hline $\begin{array}{c}\text { Lysine } \\
\text { decarboxylase }\end{array}$ & + & + & + & V & + \\
\hline $\begin{array}{c}\text { Arginine } \\
\text { dihydrolase }\end{array}$ & +- & - & - & - & - \\
\hline $\begin{array}{l}\text { Hydrogen sulphide } \\
\text { production }\end{array}$ & - & - & - & - & - \\
\hline Citrate & + & + & + & + & + \\
\hline Indole production & + & + & + & - & + \\
\hline $\begin{array}{l}\text { tryptophane } \\
\text { deaminase }\end{array}$ & - & - & + & + & - \\
\hline Urea hydrolysis & - & - & + & - & - \\
\hline $\begin{array}{l}\text { O- nitrophenyl- } \beta \text { - } \\
\text { galactopyranoside }\end{array}$ & - & - & - & + & + \\
\hline gelatin hydrolysis & + & + & V & + & + \\
\hline Xylose & - & - & - & - & - \\
\hline Raffinose & - & + & + & - & + \\
\hline Glucose & + & + & + & + & + \\
\hline Manitol & + & + & + & - & + \\
\hline Sorbitol & + & - & + & - & - \\
\hline Sucrose & + & - & + & - & + \\
\hline Malonate & - & + & - & + & - \\
\hline Arabinose & - & + & - & - & - \\
\hline Lactose & + & - & - & + & - \\
\hline
\end{tabular}

Abbreviations: V., Vibrio; V, Variable strains; -Ve, Gram negative; (+), Positive result; (-), Negative result.

\section{DISCUSSION}

Fish larval communities have attracted a lot of attention and great importance during the last two decades as a tool to provide insights into the ecology and dynamics of marine fish larvae [23]. Furthermore, less knowledge was recorded concerning the bacterial disease affecting the coral reef early stage fish larvae in the Red Sea [24]. Information is essentially and needed as a tool to manage the Red Sea fisheries [25]. So, this study was designed to detect the prevalence of bacterial fish pathogens 
incriminated in infection and mortalities of the coral reef fish larvae. Mainly, uncontrolled microbial diseases lead to heavy financial losses in aquaculture industries that threaten their growth and sustainability. Larval mortality has been related to to multiple environmental factors, feeding state, , high water temperature, predation and microbial infection.Bacteria are the main pathogenic agents in the aquaculture industry [26]. Vibriosis is the primary disease of marine and estuarine fish in both natural and commercial production systems throughout the world. Vibriosis is caused by species from the genera Vibrios [27]. These pathogens are responsible for mortalities of fish larvae [28].

Table (3): Prevalence of infection of early fish stages with different pathogenic Vibrio spp.

\begin{tabular}{|c|c|c|c|c|c|c|c|}
\hline \multirow{2}{*}{\multicolumn{3}{|c|}{ Parameters }} & \multicolumn{5}{|c|}{ Seasons } \\
\hline & & & Winter & Spring & Summer & Autumn & Total \\
\hline \multicolumn{3}{|l|}{ No. of larvae } & 40 & 58 & 52 & 32 & 182 \\
\hline \multicolumn{3}{|c|}{ No. of infected larvae } & 10 & 19 & 45 & 27 & 101 \\
\hline \multicolumn{3}{|c|}{$\%$ of infected larvae } & 25 & 32.8 & 86.5 & 84.4 & 55.5 \\
\hline \multirow{2}{*}{\multicolumn{2}{|c|}{ V. vulnificus }} & No. & 0 & 2 & 8 & 4 & 14 \\
\hline & & $\%$ & 0 & 3.4 & 15.4 & 12.5 & 7.6 \\
\hline \multirow{2}{*}{\multicolumn{2}{|c|}{ V. parahaemolyticus }} & No. & 2 & 7 & 10 & 6 & 25 \\
\hline & & $\%$ & 5 & 12.1 & 19.2 & 15.6 & 10.4 \\
\hline \multirow[t]{2}{*}{ V. alginolyticus } & $\sum^{\pi}$ & No. & 2 & 3 & 6 & 4 & 15 \\
\hline & $\underline{\bar{\Xi}}$ & $\%$ & 5 & 5.2 & 11.5 & 12.5 & 8.2 \\
\hline \multirow[t]{2}{*}{ V. harveyi } & تृ & No. & 4 & 7 & 11 & 6 & 28 \\
\hline & 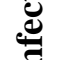 & $\%$ & 10 & 12.1 & 21.2 & 18.8 & 15.4 \\
\hline \multirow[t]{2}{*}{ V. cholerae } & & No. & 2 & 4 & 5 & 2 & 13 \\
\hline & & $\%$ & 5 & 6.9 & 9.6 & 6.3 & 7.1 \\
\hline \multirow[t]{2}{*}{ Unidentified Vibrio sp } & & No. & 0 & 1 & 4 & 6 & 11 \\
\hline & & $\%$ & 0 & 1.7 & 7.7 & 18.8 & 6 \\
\hline
\end{tabular}

In the present study, a decrease in dissolved oxygen and an increase in ammonia concentration in seawater was observed in summer and autumn compared to winter season. These variations in dissolved oxygen and total ammonia were accompanied with high prevalence rate of infection with different pathogenic Vibrio spp. This finding were in accordance with those of Haenen et al. [4]. Generally, pH in the studied site was shifted towards the alkaline range at all seasons. This indicates that human activities and run off wastes didn't cause strong changes in $\mathrm{pH}$. Other studies in Potomac River, USA conducted in 1983 reported a change in $\mathrm{pH}$ to reach $\mathrm{pH} 10$ due to human activities and run off agriculture wastes [29]. Temperature varies significantly between summer and winter, whereas the salinity shows no significant seasonal variation and does not represent a major factor affecting the changes in the seawater density. Furthermore, the high rate of infection incidence may be also related to the elevated temperature in summer due to the decrease in DO as indicated by other studies [30];[31]. It is well known that warmer water (in summer) is capable for holding less dissolved oxygen than cooler water [32]. The elevation in the level of ammonia, in autumn and summer, physical contact and the sever drop in the dissolved oxygen are the most incriminated predisposing factors for initiation, establishment and spread of infection in addition to fish immune system suppression [33]. 
Table (4): Prevalence of infection between different larvae during different seasons

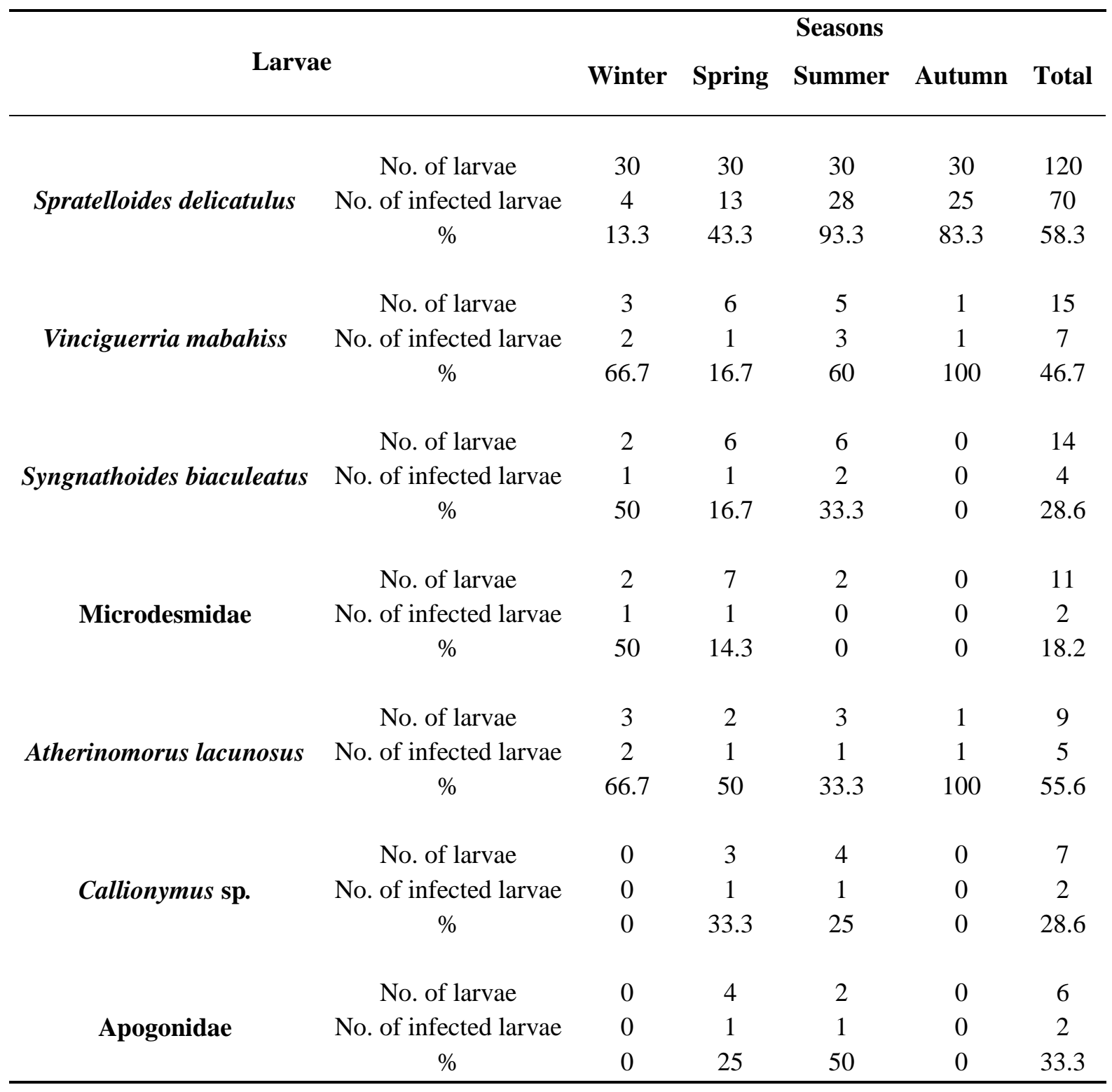

The high prevalence of larvae of demersal spawners was due to the high larval density of families with demersal eggs such as Clupeidae. Larvae of Spratelloides delicatulus (Clupeidae) were very highly abundant during all different seasons, while Dragonets (Callionymus sp.) and Apogonidae (Cardinal fishes) show the lowest prevalence rate. Dragonets (Callionymus sp.) and Apogonidae (Cardinal fishes) are absent in winter and autumn. These results were compatible with the findings of Abu El-Regal et al. [34].

The clinical examination of the infected larvae showed signs similar to Vibriosis, that were sluggish swimming movment with multiple small ulcers in cadual region and skin Petechial hemorrhage and necrosis in internal [5]. 
About 106 pure bacterial isolates from naturally infected fish larvea were identified as $V$. vulnifacus, $V$. harveyi, V. alginolyticus, V. parahaemolyticus, V. cholerae and unidentified Vibrio species by culture, morphological, and biochemical characters including the API20E gallery.

The prevalence of bacterial infection was observed during different seasons and appeared to be due to infection with certain pathogenic species of genus Vibrio. The highest prevalence rate of infection between early stage larvae was detected in summer season and this could be attributed to the increasing of human activities and thus increasing the microbiological pollution. While on the other aspect, the lowest prevalence rate of infection was recorded in winter.These findings were consistent with Hidalgo et al. [35] who reported that, the high risk of infection seems to be dependent upon the environmental conditions especially during summer. Likewise, Handeland et al. [36] reported that, the maximum and minimum values of prevalence of bacterial infection in the fish were during summer and winter respectively. All studied Vibrio species were recoverd in all seasons except V. vulnificus was absent in winter specimens. $V$. harveyi was the most frequently recoverd Vibrio spp. followed by $V$. parahaemolyticus.

Spratelloides delicatulus (Clupeidae) exhibited the highest prevalence of infection with different Vibrio spp. while the lowest prevalence infection with Vibrio spp. was recorded in Wormfishes (Microdesmidae) during different seasons. This was in agreement with the results of Tendencia [10] who recorded that Vibrio spp. consider the dominant bacterial groups obtained from the intestinal micro flora of turbot fish larvae (Scophthalmus maximus). In our point view, the colonization of Vibrio spp in association with eggs in a natural marine enviroment is logical, taking in consideration that Vibrio spp. are the predominat normal inhabitants of the marine aquatic ecosystem, and estuarine habitats. Moreover, Vibrio spp. have excellent colonization efficiency on the mucous surfaces and hence easily colonize on the eggs surface [37].

\section{CONCLUSION}

In conclusion, the high rate of infection incidence could be attributed to the increase of the sea water pollution especially in the summer season. Our investigation results indicates that the early stages fish larvae are susceptible to infection by Vibrio species which can be considered as a potential pathogen for fish larvae. Fish larvae infection was caused by $V$. alginolyticus, $V$. vulnifacus, $V$. parahaemolyticus, $V$. harveyi, V. cholera and unidentified Vibrio species.

\section{REFERENCES}

[1] Sharaan, M., Negm, A., Iskander, M., El-Tarabily, M. Analysis of Egyptian Red Sea Fishing Ports. International Journal of Engineering and Technology, 9(2):117-123, (2017).

[2] El-Asmar, H.M., Ahmed, M.H., El Kafrawy, S.B., Oubid-Allah, A.H., Mohamed, T.A., Khaled, M.A. Monitoring and Assessing the Coastal Ecosystem at Hurghada, Red Sea Coast, Egypt. J.of Env. and Earth Sci., 5(6):144-160, (2015).

[3] Nicolas, J.L., Corre, S., Gauthier, G., Robert, R., Ansquer, D. Bacterial problems associated with scallop Pecten maximus larval culture. Dis. Aquat. Org., 27: 67-76., (1996).

[4] Haenen, O.L.M., van Zanten E., Jansen R., Roozenburg I, Engelsma, M.Y., Dijkstra, A. , Boers, S. A.,Voorbergen-Laarman, M., Möller, A.V.M. Vibrio vulnificus outbreaks in Dutch eel farms since 1996: strain diversity and impact. Dis. Aquat. Org., (108): 201-209, (2014).

[5] Olafsen, J.A. Interactions between fish larvae and bacteria in marine aquaculture. Aquaculture, 200: 223-247, (2001). 
[6] De Swaef, E., Vercauteren, M., Duchateau, L., Haesebrouck, F. and Decostere, A. Experimental infection model for Vibriosis in Dover sole (Sole asolea) larvae as an aid in studying its pathogenesis and alternative treatments. Vet. Res., 49:24, (2018).

[7] El-Bouhy, Z., El-Nobi, G., El-Murr, A., Abd El-Hakim, S. Study on Vibriosis In Mugil Capito In El- Dakahlia And Damitta Governorates, Egypt. Abbassa Int. J. Aquat., 9 (1):19-35, (2016).

[8] Ramkumar, S.V., Kannapiran, E.,Palanisamy, M. Prevalence and distribution of total heterotrophic bacteria from Kottaipattinam coast, Palk Strait, Southeast coast of India. Scholars research library. Archives of Appl. Sci. Res., 3(5):593-59, (2011).

[9] Vandenberghe, J., Thompson, F.L., Gomez-Gil, B., Verdonck, Y., Li, L., Sorgeloos, J., Li, P., $\mathrm{Xu}, \quad$ H.S. Swings, J. Vibriosis associated with Penaeus chinensis larvae in Chinese shrimp hatcheries. Aquaculture, 169: 121-132, (1998).

[10] Tendencia, E.A. Vibrio harveyi isolated from cage-cultured seabass Latescal carifer Bloch in the Philippines. Aquaculture Research, 33:455-458, (2002).

[11] Nicolas, J.L., Basuyaux, O., Mazurie, J., Thebault, A. Vibrio carchariae, a pathogen of the abalone Haliotis tuberculata. Diseases of Aquatic Organisms, 50:35-43, (2002).

[12] Thompson, F.L., Hoste, B., Vandemeulebroecke, K., Engelbeen, K., Denys, R., Swings, J. Vibrio trachuri is a junior synonym of Vibrio harveyi. Int. J. Syst. Evol. Microbiol. , 52:973976, (2002).

[13] Liu, P.C., Lin, J.Y., Chuang, W.H., Lee. K.K. Isolation and characterization of pathogenic Vibrio harveyi ( $V$. carchariae) from the farmed marine cobia fish Rachycentron canadum L. with gastroenteritis syndrome. World Journal of Microbiology and Biotechnology, 20:495-499, (2003).

[14] Tendencia, E.A. The first report of Vibrio harveyi infection in the sea horse Hippocampus kuda Bleekers 1852 in the Philippines. Aquaculture Research, 3: 1292-1294, (2004).

[15] Hoffmann, M., Eric, W., Peter, CH., Cheristine, E., Fischer, M., Steven, R. PCR-based method for targeting 16S-23S rRNA intergenic spacer regions among Vibrio species. BMC Microbiology, 10: 90,(2010).

[16] Buller, N.B.. Bacteria from Fish and Other Aquatic Animals: A Practical Identification Manual. CABI Publishing, Wallingford, UK, p. 361, (2004).

[17] Abu El-Regal, M.A., Abu Zeid, M.M., Hilal, A., Maaty, M.M. Adult and larval fish assemblages in Mabahis Bay, northern Red Sea, Egypt. Int. J. of Environ. Sci. and Eng., 5: 111-126, (2014).

[18] American Public Health Association (APHA). Standard Methods for the Examination of Water and Wastewater. $\left(20^{\text {th }}\right)$ Edn. APHA Inc.Washington DC., (1998).

[19] Abu El-Regal, M.A., Abdelrahman, M.M., Abdelghany, A.S. Investigations on larvae of commercial fish from Hurghada, Red Sea with notes on the spawning seasons and grounds of some species. Iran. J. of F. Sci.,18(3) 476-496, (2019).

[20] Santos, Y., Pazos, F., Barja, J. Flexibacter maritimus, causal agent of flexibacteriosis in marine fish. International council for the exploration of the sea, Edited by Gilles Olivier and Pendant son association avec fisheries and oceans Canada, halifax, novascotia, Canada B3J 2S7, (1999).

[21] Farmer, J.J., Hickman-Brenner, F.W. The genera Vibrio and Photobacterium. In: The Prokaryotes. A Handbook on the Biology of Bacteria: Ecophysiology, Isolation, Identification, Applications, (2nd) edn. pp. 2952-3011, (1992).

[22] Alsina, M., Blanch, A.R. A set of keys for biochemical identification of environmental Vibrio species. J. of Appl. Bacteriol., pp. 79-85, (1994). 
[23] Moser, H. G., Smith, P. E. Larval fish assemblages of the California Current Region and their horizontal and vertical distributions across a front. Bulletin of Marine Science, 53: 645-691, (1993b).

[24] Abd El-Galil, M.A.A., Hashem, M. Epidemiological and bacteriological studies on tenacibaculosis in some Red Sea fishes, Egypt. International Journal of Environmental Science and Engineering (IJESE), (3): 25- 32, (2012).

[25] Abu El-Regal, M. A. Ecological studies on the ichthyoplankton of coral reef fishes in Hurghada, Red Sea, Egypt. PhD thesis. Marine Science Dept., Faculty of Science, Suez Canal University, Ismailia, Egypt. PP:225, (2008).

[26] Garrido, S., Be-Hamadou, R., Santos, A.M.P., Ferreira, S., Teodosio, M.A, Cotano, U., Irigoien, X., Peck, M.A., Saiz,E., Re, P. Born small, die young: Intrinsic, size-selective mortality in marine larval fish. Sci Rep., 5:17065, (2015).

[27] Silva, Y.J., Costa, L., Pereira, C., Mateus, C., Cunha, A., Calado, R., Gomes, N.C.M., Pardo, M.A., Hernandez, I., Almeida, A. Phage therapy as an approach to prevent Vibrio anguillarum infections in fish larvae production. PLoS ONE 9:e114197, (2014).

[28] Rodrigo, R., Claudio, D., Miranda, J.S., Jaime, R. First Report of Vibrio tubiashii Associated with a Massive Larval Mortality Event in a Commercial Hatchery of Scallop Argopecten purpuratus in Chile. Front Microbiol., 7:1473, (2016).

[29] Blanchard, S.F. Water quality of Potomac River at Chain Bridge of Washington. U.S. Geological Survey Open File Report, 10:83-147, (1983).

[30] Mostafa, S.E., Kristen, N.S., Aharon, O., Gutierrez, M.C., Antonio, V., Lee, R.K. Haloferax sulfurifontis sp. nov., a halophilicarchaeon isolated from a sulfide- and sulfur-rich spring. Int. J. of Systematic and Evolutionary Microbiol., 54: 2275-2279, (2004).

[31] Hashem, M., Abd el-Latif, H. M.R., Abogabal, I. I. PCR Targeted the 16S-23S rRNA intergenic spacer for detection of Vibrio species affecting Longnose Parrot fish (Hipposcarus harid) inhabiting the Red Sea basin at Hurghada, Egypt.1st International Conference And Exhibition (Central Laboratory), (2017).

[32] Badran, M. I. Dissolved oxygen, chlorophyll a and nutrients: seasonal cycles in waters of the Gulf Aqaba, Red Sea, Aquat. Ecosys. Health Manage .4 (2):139 -150, (2001).

[33] Suomalainen, L.R., Tiirola, M., Valtonen, E.T. Influence of rearing conditions on Flavobacterium columnare infection of rainbow trout, Oncorhynchus mykiss (Walbaum). J. of F. Dis., 28(5): 271-277, (2005).

[34] Abu El-Regal, M., Abu Zeid, M. M., Hellal, A. M., Maaty, M. M. Abundance and diversity of larvae of reef fish in Mabahiss Bay, on the Egyptian Red Sea coast. Egyptian Journal of Aquatic Biology and Fisheries. 18:61-77, (2015).

[35] Hidalgo, A., Palma, H., Oberg, C., Fonseca-Salamanca, F., Oestrus ovis infection of grazing sheep during summer in southern Chile. Pesq. Vet. Bras., 35 (6), (2015).

[36] Handeland, K., Davidson, R. K., Viljugrein, H., Mossing, A., Meisingset, E. L., Heum, M., Strand, O., Isaksen, K. Elaphostrongylus and Dictyocaulus infections in Norwegian wild reindeer and red deer populations in relation to summer pasture altitude and climate. International Journal for Parasitology: Parasites and Wildlife, 10: 188-195, (2019).

[37] Beatrize, M. Bacteria associated with sardine (Sardina pilchardus) eggs in a natural environment (Ría de Vigo, Galicia, northwestern Spain). FEMS Microbiology Ecology, 44 (3): 329-334, (2003). 